\title{
Assessing wetland services for improved development decision-making: a case study of mangroves in coastal Bangladesh
}

\author{
Md. Mijanur Rahman (D) Y Yong Jiang • Kenneth Irvine
}

Received: 21 April 2017 / Accepted: 8 January 2018/Published online: 8 February 2018

(C) The Author(s) 2018. This article is an open access publication

\begin{abstract}
Mangroves provide valuable ecosystem services for the wellbeing of coastal communities. Assessment and valuation of these mangroves services are increasingly advocated in development and conservation decision-making. Translating the values of services into more explicit monetary terms requires understanding of stakeholder activities, socio-economic context and local organizational structure to effectively support decision-making. Based on a survey of 100 households of three villages of Sundarban in Bangladesh, mangroves services to local communities were identified and their economic values estimated. The households perceived 18 mangroves services, of which capture fisheries, fuel
\end{abstract}

The study was conducted in the UNESCO-IHE Institute for Water Education, P.O. Box 3015, 2601 DA Delft, The Netherlands.

Md. M. Rahman ( $₫)$

Environmental Research and Development Alternatives, 14/12, Babor Road, Block-B, Mohammadpur,

Dhaka 1207, Bangladesh

e-mail: mijan_nir@yahoo.com

Y. Jiang $\cdot$ K. Irvine

IHE Delft Institute for Water Education, P.O. Box 3015,

2601 DA Delft, The Netherlands

e-mail: k.irvine@un-ihe.org

K. Irvine

Aquatic Ecology and Water Quality Management,

Wageningen University, P.O. Box 47,

6700 AA Wageningen, The Netherlands energy, storm protection, habitat for fish breeding and nursery grounds and aesthetic enjoyment were ranked the most important. For provisioning services, households obtained important monetary benefits annually from capture fishery (US\$ 976 per ha), fuel energy (US\$ 80 per ha), honey (US\$ 53 per ha) and fodder (US\$ 26 per ha). The average annual willingness to pay for storm protection, erosion control and habitat for fish breeding and nursery services were estimated, respectively, as US\$ 13 per ha, US\$ 2 per ha and US\$ 9 per ha. However, unsustainable exploitation and salinity intrusion impacted the services provided by mangroves. This study provides an important insight into the services and values of mangroves for local welfare, and thus can inform policy for protection and better use of mangrove resources.

Keywords Mangroves - Coastal wellbeing · Valuation · Economic value - Welfare policy

\section{Introduction}

Mangrove wetlands, found globally in tropical and sub-tropical coastal areas (FAO 2010), offer a wide range of ecosystem provisioning, regulating, cultural and supporting services (MEA 2005). They support the livelihoods of coastal communities, play crucial 
roles in protecting them from natural hazards, and are habitat to a rich diversity of species (Daily 1997; Ronnback 1999; Costanza and Farber 2002; Walters et al. 2008). Qualitative description of such biospheresupporting attributes not captured in traditional commodity markets is quite straightforward, but is often less persuasive in decision-making than more quantitative valuation (Daily et al. 1997; Alongi 2002; Chee 2004; Curtis 2004). While translating the value of ecosystem services into more explicit monetary terms is increasingly advocated (Bateman et al. 2013; Mukherjee et al. 2014), it requires sufficient knowledge of stakeholder activities and preferences, the socio-economic context and local administrative structures to effectively support decision-making. It also, fundamentally, requires methodology that is able to measure and value not only the substantive provisioning goods that can be obtained from the environment, but also the importance of those supporting, regulating and cultural services that are less amenable to direct economic valuation.

In Bangladesh, mangroves are located along the coast. While previously extensive, they are now confined to the south-west Sundarban area and offshore islands (Islam and Wahab 2005). The Sundarban mangroves lie across the delta of three major rivers-Ganges, Brahmaputra and Meghna shared between Bangladesh and India. They form the world's largest single tract of mangrove ecosystem that in Bangladesh covers a core area of $5970 \mathrm{~km}^{2}$, with a peripheral buffer zone of an additional $3640 \mathrm{~km}^{2}$ (IUCN 2014). The Sundarban mangroves, bordered by the Baleswar River to the east and the Harinbanga River to the west, extend up to shorelines of the Bay of Bengal to the south.

Sundarban has a rich biodiversity, and provides a range of provisioning services of food, timber, and other raw materials; regulating services of storm protection, erosion control and carbon sequestration; cultural services supporting tourism and recognised heritage; and supporting habitats important for local fishery and as nursery grounds for offshore ones (Islam and Wahab 2005; Biswas et al. 2007; Hoq 2007; Iftekhar 2008; Iftekhar and Takama 2008; Getzner and Islam 2013; Uddin et al. 2013a). Because of their strategic importance, the Sundarban mangrove was declared a forest reserve in 1878 under the Forest Act of 1865. Various policy instruments further promoting protection culminated with the establishment of the
Environment Policy of 1992 (Khan 2014), which aimed for sustainable environmental management of the country through conservation. The Sundarban mangrove was designated as a Ramsar site in 1992 and an UNESCO World Heritage site in 1997. The Bangladesh Environment Conservation Act 1995, amended in 2010, further established a $10-\mathrm{km}$ wide buffer zone surrounding the mangrove reserve, which in 1999 was declared an ecologically critical area (ECA). Within the Sundarban buffer zone, livelihood interventions support environmental and biodiversity conservation, and legislate against activities that may degrade the environment (FD 2010). Improving the integrity of natural environment including mangroves constitutes an important component of integrated coastal zone management (ICZM) (MoWR 2005). The Sundarban is currently managed under the authority of the Bangladesh Forest Department. An integrated 10 year plan (2010-2020) focuses on resource management, climate change, co-management, eco-tourism and wetland management (FD 2010).

Despite their recognised importance and legal status, the Sundarban mangroves have been degrading at an alarming rate from conversion to shrimp farming, land reclamation, and over-exploitation for firewood and fisheries (Islam and Wahab 2005; Rahman et al. 2010; Hussain 2014). In Bangladesh, shrimp farming has expanded in the coastal areas at the cost of local resources including artisanal fishing and forestry (Pokrant 2014). At the same time, the region is increasingly exposed to frequent storm surges and cyclones (Uddin et al. 2013b), affecting human livelihoods and security (IPCC 2014), while dominance of policies for traditional economic development that impact mangroves continue (Iftekhar and Islam 2004; Islam and Wahab 2005). Recommendations for integrated resource management lack effective implementation (Hussain 2014).

Previous studies have documented the status and use of ecosystem services provided by Sundarban mangroves (Islam and Wahab 2005; Biswas et al. 2007; Hoq 2007; Iftekhar 2008; Getzner and Islam 2013), but few have quantified those services and estimated their monetary value (Brander et al. 2012; Uddin et al. 2013a; Haque and Aich 2014). There is a crucial gap in understanding how the Sundarban ecosystem supports the local and regional economy, to what extent the policy dialogue can be strengthened, 
and how is the awareness of local communities who depend on the wetlands. The aim of this study is to examine the ecosystem services provided by Sundarban mangroves as perceived by local coastal communities and their monetary value. This study seeks to inform local authorities to improve mangroves management and development decision-making.

\section{Materials and methods}

\section{Study areas}

The Sundarban mangroves reserve and its impact zone in Bangladesh are under the administration of five coastal districts. Human settlement is restricted inside the reserve. The impact zone is inhabited by over 3.5 million people across 1302 villages. These communities are allowed to extract mangroves products in the forest reserve with permission by the forest department. The major livelihood activities consist of capture fishery, wood and mangroves palm collection, honey collection, snail and oyster collection, shrimp farming and agriculture (Biswas et al. 2007; Giri et al. 2007; FD 2010). For this study, three villages (Shinghertoly under the Munshigonj Union Council, Burigoalini and Nil Dumur (Bhamnia) under the Burigoalini Union Council) in the Shyamnagar subdistrict of the Satkhira district were selected because of their close proximity to the Sundarban mangroves (Fig. 1). Each village is headed by an elected member representing the village in the local Union Council. Union Council is the lowest independent administrative unit of the local government of Bangladesh and consisting of a chairman and 12 members. All villages avail directly and indirectly on the mangroves. According to the local Union Council, there were 1142 households with a total population of 5292 in the three surveyed villages.

\section{Research design and data collection}

The ecosystem services approach of TEEB (2010) was adopted to assess and value the services that local communities derive from the Sundarban mangroves. This approach links ecosystem services to human well-being, making the economic benefits derived from them more explicit to provide a clearer means of integration with decision-making (NRC 2005; Turner et al. 2008; TEEB 2009). The services provided by the mangroves wetlands were identified and assessed through: (1) analyzing mangroves wetlands context (resources use, land use, socio-economic status, natural disasters, and drivers of changes) and relevant stakeholders who benefit from them; (2) quantifying those services that sustain and benefit local communities; and (3) estimating the values of mangroves services based on ecological, socio-cultural and economic indicators.

Both qualitative and quantitative data were collected and used for analysis. Data were collected through focus group discussions and household surveys. Focus group discussions, organized with 10-15 people in each of the three villages, were conducted to understand household conditions, livelihood activities, resources use, and vulnerability of the villages. The household surveys were conducted by face-toface interviews based on a semi-structured questionnaire in the three selected villages from 27 November 2014 to 5 January 2015. The questionnaire was pretested before implementing the household surveys to reduce the risk of inconsistency and ambiguity. Following the pre-test, a total of 100 households were selected from the three targeted villages randomly based on the lists of households provided by village leaders, among which 34 were from Shinghertoly, 36 from Burigoalini and 30 from Nil Dumur.

The questionnaire for household surveys consisted of four sections. The first section assessed socioeconomic background of households and their livelihoods. The second section focused on perceptions on ecosystem services provided by mangroves and their importance to local communities; including the ranking of importance of a list of goods and services assembles from the literature. The third section was on factors influencing livelihoods and local mangroves management. The fourth and final section included valuation questions eliciting households' willingness to pay (WTP) for selected regulating and supporting services of mangroves that have non-market value.

Three types of mangroves services were selected to elicit WTPs of households, including two regulating services (storm protection and erosion control) and one supporting service (habitat for fish breeding and nursery ground). As these services have non-market value, a hypothetical market scenario was specified within which to elicit WTPs of households for these services. Specifically, respondents, first, were briefed 
Fig. 1 Location of Sundarban mangroves wetlands and three villages (i.e., Shinghertoly,

Burigoalini and Nil Dumur) surveyed at Shyamnagar upazila (sub-district) of the Satkhira district

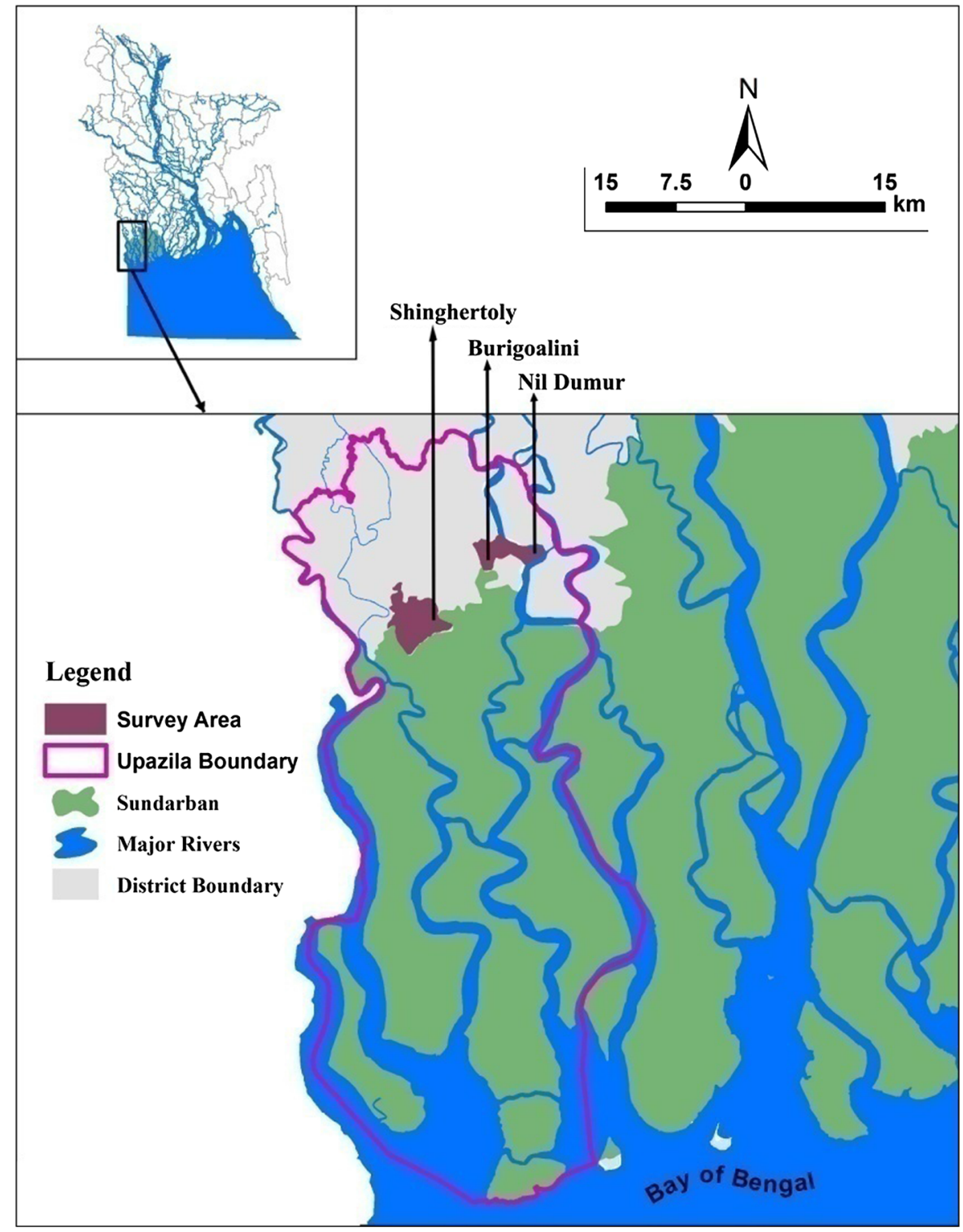

about the considered regulating and supporting services that local communities receive from mangroves and how livelihood relies on these services that will be endangered and eventually lost if mangroves are not conserved and continually developed or degraded. In this context, the respondents were then presented a scenario stating that mangroves can be conserved and protected from development or degradation and thus the regulating and supporting services benefiting local communities can be maintained if sufficient monetary contribution for mangrove conservation can be raised from households. With this scenario, a payment card was provided that had 20 different options of annual monetary contribution from which the respondents were asked to choose as their maximum WTPs. The values shown on the payment card were proposed based on the socio-economic conditions of households in Sundarban, and further modified following discussion with 10 villagers. The values, presented in local currency (BDT-Bangladeshi Taka), were converted to US\$ using a conversion rate of BDT 78 to US\$1, corresponding to December 2014. Respondents were allowed to specify values other than those given on the payment card. The valuation question was followed by 
a question eliciting reasons for the choice. An example of the payment card is included below:

\begin{tabular}{|c|c|c|c|}
\hline Don & o 1000 BDT & o $2250 \mathrm{BDT}$ & о 3500 BDT \\
\hline o $0 \mathrm{~B}$ & o & $\mathrm{T}$ & o 3750 BDT \\
\hline 25 & o $1500 \mathrm{l}$ & DT & 04000 \\
\hline 500 & o 1750 & о 3000 BDT & o 4250 BDT \\
\hline $750 \mathrm{BDT}$ & o 2000 BDT & o $3250 \mathrm{BDT}$ & o More (specif \\
\hline
\end{tabular}

Data analysis

The socio-economic backgrounds of survey respondents were summarized using descriptive statistics. Economic values of provisioning services were estimated based on the net market values of mangroves products collected or utilized by the households, which were calculated by multiplying the amount of mangroves products harvested and their unit price sold to the local traders. Economic value of mangrove products were amalgamated by total per village by multiplying the annual net market values of collected products per household and the number of households involved in harvesting.

Economic values of regulating and supporting services were estimated by the household WTP for those services. In our analysis, WTP responses were excluded from the analysis if: (1) no reason was given by the respondents explaining their WTPs; (2) the respondent considered the government being mainly responsible for the payment; or (3) the respondent was unable to give his WTP values. Analysis of variance (ANOVA) was used to compare household WTPs for the considered ecosystem services across villages. Annual average economic values of regulating and supporting services were estimated per household from the mean household WTP values. Economic values per village were estimated by multiplying the average value of services per household and the number of households in a village stated WTP value.

The annual economic values of mangroves services for all villages (1302) within the 10-km Sundarban Impact Zone (SIZ) were estimated by multiplying the estimated economic values of mangroves services per village and the total number of villages. Economic values were standardized to per hectare (ha) by dividing the value for all villages in SIZ by the area of those villages $\left(3640 \mathrm{~km}^{2}\right.$, IUCN 2014). We assume that the studied three villages are representative of other villages in the SIZ based on similar socioeconomic characteristics of the households and access to the mangroves resources for livelihoods and subsistence (Halim et al. 2001; Shah and Khan 2014). Our estimates of the annual economic values provide a preliminary indication of the services of Sundarban mangroves in SIZ, which can serve as the starting point for future research.

\section{Results}

Socio-economic status of households

\section{Profile of respondents' households}

The demographical and socio-economic background of the surveyed households in three villages reflected the status of local population living in the SIZ (Table 1$)$. The majority (62\%) of the respondents were aged between 31 and 60 years old, with $13 \%$ above 60 and $25 \%$ below 30 . Males accounted for $86 \%$ of respondents. The majority of the respondents were native people, with $90 \%$ having lived in the study areas since their birth. Literacy rate was estimated as $62 \%$. Tube-wells and ponds were the sources of fresh water supply for 34 and $66 \%$ of the respondents, respectively. Rain water was also harvested and stored in plastic tank for use during dry periods by $25 \%$ of respondents. Almost 34\% of the respondents had livestock (cows and goats) and used mangroves leaves as fodder particularly for goats. Nearly all (92\%) respondents were dependent on mangroves for firewood.

Land tenure was unevenly distributed among households. The average size of land owned by the surveyed households was 0.97 acres (median $=0.16$ ) ranging from 0 to 11.6 acres per household. While the majority (or $73 \%$ ) of the households had land below one acre (average 0.17 acres per household), this altogether occupied only $15 \%$ of the total land; $7 \%$ of the households owned almost $60 \%$ of the total land (average 8.34 acres per household). There were $8 \%$ landless households who lived on public land around the embankment. Nearly $47 \%$ of the households did not have any cultivable land except their homestead. 
Table 1 Summary of socio-economic characteristics of survey respondents of studied three villages (i.e., Shinghertoly, Burigoalini and Nil Dumur) in SIZ

\begin{tabular}{|c|c|c|}
\hline Attribute & Level & $\%$ of respondents $(n=100)$ \\
\hline \multirow[t]{4}{*}{ Age group } & $\leq 30$ years & 25 \\
\hline & $31-45$ years & 36 \\
\hline & $46-60$ years & 26 \\
\hline & $\geq 61$ years & 13 \\
\hline \multirow[t]{2}{*}{ Years of residence } & Since birth & 90 \\
\hline & $10-44$ years & 10 \\
\hline \multirow[t]{2}{*}{ Gender } & Male & 86 \\
\hline & Female & 14 \\
\hline \multirow[t]{4}{*}{ Education } & No formal education & 38 \\
\hline & Primary (I-V) & 26 \\
\hline & Secondary (VI-XII) & 34 \\
\hline & Tertiary & 2 \\
\hline \multirow[t]{3}{*}{ House size } & Small size & 45 \\
\hline & Medium size & 43 \\
\hline & Large size & 12 \\
\hline \multirow[t]{3}{*}{ Access to drinking water } & Tube well & 34 \\
\hline & Pond & 66 \\
\hline & Rainfall & 24 \\
\hline \multirow[t]{2}{*}{ Livestock } & Households own livestock & 34 \\
\hline & Use mangroves leaves as fodder & 29 \\
\hline \multirow[t]{3}{*}{ Fuel energy source } & Mangroves & 86 \\
\hline & Non-mangroves & 8 \\
\hline & Both & 6 \\
\hline \multirow[t]{5}{*}{ Land ownership } & Landless & 8 \\
\hline & $0.10-1.00$ acre & 73 \\
\hline & $1.01-3.00$ acres & 10 \\
\hline & $3.01-5.00$ acres & 2 \\
\hline & $>5.00$ acres & 7 \\
\hline \multirow[t]{4}{*}{ Land use } & Only homestead & 47 \\
\hline & Homestead and shrimp-fish farming & 22 \\
\hline & Homestead and agriculture & 10 \\
\hline & Homestead and land leasing & 13 \\
\hline
\end{tabular}

For households with more available land, $25 \%$ engaged in shrimp-fish farming and $10 \%$ in agriculture.

\section{Livelihood activities and income}

The surveyed households were dependent on 18 types of mangroves and non-mangroves based activities for their livelihoods (Table 2). Specifically, up to $74 \%$ of the households obtained their income mainly from mangrove based livelihood activities, including $63 \%$ from directly collecting mangrove products, such as crabs and shrimp fry, honey, wood, and capture fishery, and $11 \%$ from business or trades related to mangrove products. The average time that households spent in mangrove-based livelihood activities varied, depending on the specific activity. Collecting mangrove products was largely a year round activity, except for honey, which was harvested between April and June. Households spent on average 180 days annually in collection of crabs, shrimp fry and capture fishery, 24 days in wood cutting, and 60 days in honey harvesting. Conversely, main earnings of almost $26 \%$ households were reliant on shrimp-fish farming and 
Table 2 Main and secondary occupations and livelihood activities of surveyed households $(n=100)$ of three villages (i.e., Shinghertoly, Burigoalini and Nil Dumur) in SIZ

\begin{tabular}{|c|c|c|c|c|c|c|}
\hline \multirow[t]{2}{*}{ Livelihood activities } & \multirow{2}{*}{$\begin{array}{l}\text { Main sources (\% } \\
\text { of households) }\end{array}$} & \multirow{2}{*}{$\begin{array}{l}\text { Secondary } \\
\text { sources (\% of } \\
\text { households) }\end{array}$} & \multicolumn{4}{|l|}{ Period of engagement } \\
\hline & & & Period & Day/month & Month/year & Day/year \\
\hline \multicolumn{7}{|l|}{ Mangroves based } \\
\hline Crab collection & 31 & 11 & Year round & 15 & 9 & 135 \\
\hline Shrimp fry collection & 19 & 27 & Year round & 18 & 10 & 180 \\
\hline Fishing (shrimp-fish) & 13 & 4 & Year round & 13 & 10 & 132 \\
\hline Honey collection & & 7 & April to June & 30 & 2 & 60 \\
\hline Wood collection & & 1 & Year round & 2 & 12 & 24 \\
\hline Crab business & 6 & 3 & Year round & 24 & 11 & 265 \\
\hline Shrimp-fish business & 3 & 2 & April to November & 22 & 5 & 110 \\
\hline Shrimp fry business & 2 & 3 & Year round & 26 & 11 & 286 \\
\hline Honey business & & 2 & April to June & 30 & 3 & 90 \\
\hline \multicolumn{7}{|l|}{ Non-mangroves based } \\
\hline Shrimp-fish farming & 12 & 10 & March to December & 30 & 10 & 300 \\
\hline Small business & 8 & 11 & Year round & 26 & 12 & 312 \\
\hline Tailoring & 2 & 1 & Year round & 30 & 12 & 360 \\
\hline Wage labour & 2 & 25 & Year round & 16 & 8 & 128 \\
\hline Driving & 1 & 4 & Year round & 24 & 8 & 192 \\
\hline Service & 1 & 4 & Year round & 30 & 12 & 360 \\
\hline Agriculture & & 7 & June to September & 30 & 4 & 120 \\
\hline Land leasing & & 13 & Year round & 30 & 12 & 360 \\
\hline House rental & & 2 & Year round & 30 & 12 & 360 \\
\hline
\end{tabular}

small business. Of the livelihood activities, shrimp fry collection and wage labouring were the important secondary sources of income and almost 27 and $25 \%$ households were engaged in these activities, respectively. The majority of households were engaged in more than one activity for their earnings. More than half of the households were involved in two activities, $29 \%$ of households in three activities, and $11 \%$ of households only on a single activity for their livelihoods.

The annual average net income of households was US\$ 1478 ranging from US\$ 358 to US\$ 8885. The majority $(76 \%)$ of the surveyed households had net income below US\$2001, and a small number (8\%) of the households had income above US\$ 3000 (Fig. 2).

Overall, the majority (or about $80 \%$ ) of the households were dependent on mangroves for all or part of their income (Fig. 3). Among these households, contribution of mangrove products ranged from $1-20$ to $100 \%$ of income, with almost $35 \%$ of households entirely reliant on the mangroves.
Sundarban mangroves wetland services

\section{Mangroves wetland services perceived by the households}

In the survey, the households identified 18 types of ecosystem services from mangroves, which can be grouped into provisioning, regulating, cultural and supporting services (Table 3). Provisioning services included capture fishery, fuel woods, construction materials, fodder materials, water supply, and honey. Capture fishery encompassed fish, crabs, shrimp, and shrimp fry and considered important by nearly $79 \%$ of the households. Around $92 \%$ of the households highlighted that mangroves wood, leaves, and twigs were important as fuel. Construction materials of wood, stem and palm (golpata) from mangroves were identified as important by nearly $47 \%$ of the households for fencing and roofing of the house. Collection of mangroves leaves as fodder for goats was important for almost $29 \%$ of households. Extraction of brackish 


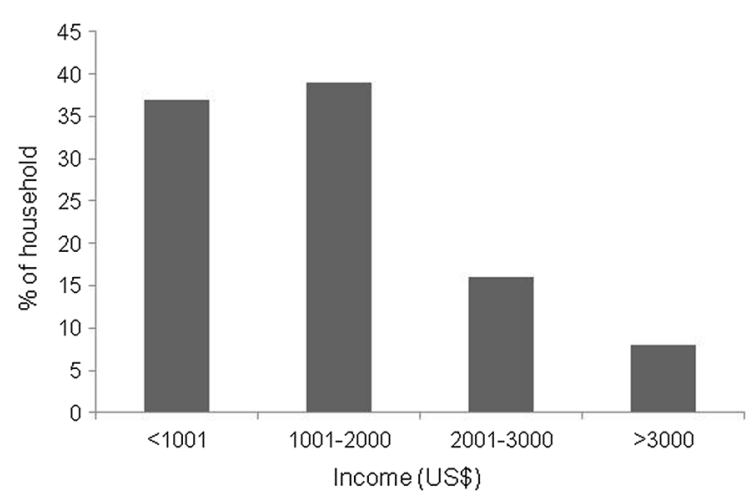

Fig. 2 Annual average net income of surveyed households $(n=100)$ of three villages (i.e., Shinghertoly, Burigoalini and Nil Dumur) in SIZ

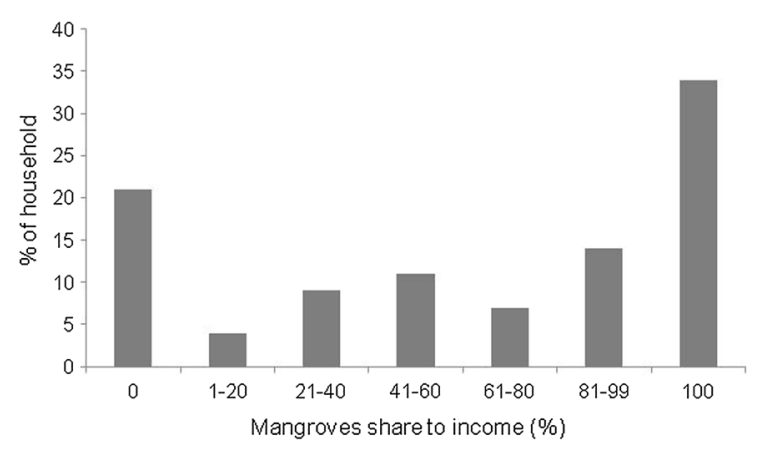

Fig. 3 Contribution of mangroves to the income of surveyed households $(n=100)$ of three villages (i.e., Shinghertoly, Burigoalini and Nil Dumur) in SIZ

water was considered important by $22 \%$ of the households who involved in shrimp and crab farming. Honey collection was important for $7 \%$ of the households.

Of the regulating services, storm protection was considered important by nearly all of the surveyed households. Other regulating services considered important were erosion control $(60 \%)$, flood mitigation $(56 \%)$, climate regulation (49\%), flow regulation (39\%), and supply of fresh air for breathing (33\%). Sundarban mangroves were considered important for cultural services such as aesthetics, tourism and recreation, heritage and spiritual inspiration. Aesthetic service was valued by nearly all of the households. Tourism and recreational service was identified as important by almost $77 \%$ of the households. The services of heritage and spiritual inspiration were appreciated by 18 and $11 \%$ of the households, respectively. The role of mangroves as supporting habitat for fish breeding and nursery grounds as well as for flora and wildlife were recognized by almost all households.

There was a large range and importance of provisioning services harvested by the households (Table 4). Annual household harvest of fishery products were on average 0.54 metric tonnes $(\mathrm{mt})$ for crabs ( $\mathrm{n}=42$, median $=0.43$ ), $0.51 \mathrm{mt}$ for fish and shrimp $(\mathrm{n}=17$, median $=0.45)$, and a total of 52,115 units for shrimp fries $(n=45$, median $=43,200)$. The households collected and utilized mangroves woods, leaves, twigs and fruits with an estimated average amount of $1.68 \mathrm{mt}$ per year per household $(\mathrm{n}=92$, median $=1.44)$. The annual harvest of honey was $0.16 \mathrm{mt}$ per household $(\mathrm{n}=7$, median $=0.11)$.

\section{Ranking of mangroves wetland services by the households}

The identified wetland services were ranked high, medium or low by the households surveyed according to their degree of importance (Fig. 4). The services ranked of high importance by the majority ( $\geq 50 \%$ ) of the households included capture fishery, fuel energy, storm protection, habitat for fish breeding and nursery, and aesthetics. Of the provisioning services, capture fishery was considered highly important by nearly $74 \%$ of the households, but of medium and low importance by 18 and $8 \%$ of the households, respectively. The mangroves use for fuel energy was rated high, medium and low by 66,20 and $6 \%$ of the households, respectively. In contrast, brackish water supply, honey, and fodder materials were ranked high by a few households. Out of six regulating services, storm protection was rated high by the most (94\%) households. The aesthetic features of Sundarban mangroves were valued with high importance by $68 \%$ of the households. Regarding the supporting services, the importance of mangroves as the habitat for fish breeding and nursery ground was rated high by $93 \%$ of the households.

Factors influencing local livelihoods and mangroves management

A large range of factors were identified by the households surveyed affecting mangroves management and local livelihoods (Fig. 5). The major threats to mangrove habitats and livelihoods were considered to be non-compliance of laws and corruption, salinity 
Table 3 Mangroves services perceived as important by surveyed households $(n=100)$ of three villages (i.e., Shinghertoly, Burigoalini and Nil Dumur) in SIZ

\begin{tabular}{|c|c|c|}
\hline Sl. & Mangroves wetland services & Percentage of surveyed households (\%) \\
\hline$A$ & Provisioning services & \\
\hline 1 & Capture fishery (crabs, shrimp fry, shrimp and fish) & 79 \\
\hline 2 & Fuel energy & 92 \\
\hline 3 & Honey & 7 \\
\hline 4 & Fodder materials & 29 \\
\hline 5 & Brackish water supply & 22 \\
\hline 6 & Construction materials & 47 \\
\hline$B$ & Regulating services & \\
\hline 7 & Storm protection & 100 \\
\hline 8 & Erosion control & 60 \\
\hline 9 & Flood control & 56 \\
\hline 10 & Climate regulation & 49 \\
\hline 11 & Flow control & 39 \\
\hline 12 & Gas regulation & 33 \\
\hline$C$ & Cultural services & \\
\hline 13 & Aesthetic information & 96 \\
\hline 14 & Eco-tourism and recreation & 77 \\
\hline 15 & Heritage value & 18 \\
\hline 16 & Spiritual inspiration & 11 \\
\hline$D$ & Supporting services & \\
\hline 17 & Habitat for fish breeding and nursery & 98 \\
\hline 18 & Habitat for flora and wildlife & 96 \\
\hline
\end{tabular}

Table 4 Quantity of provisioning services of mangroves derived by surveyed households $(\mathrm{n}=100)$ of three villages (i.e., Shinghertoly, Burigoalini and Nil Dumur) in SIZ

\begin{tabular}{lll}
\hline S1. & Provisioning services & Annual quantity \\
\hline 1 & Capture fishery & \\
& Crabs & $0.54 \mathrm{mt} /$ household \\
& Shrimp fry & $52,115 \mathrm{unit}$ fry/household \\
& Shrimp and fish & $0.51 \mathrm{mt} /$ household \\
2 & Fuel energy & $1.68 \mathrm{mt} /$ household \\
3 & Honey & $0.16 \mathrm{mt} /$ household \\
\hline
\end{tabular}

intrusion, frequent extreme events such as storm surges, cyclones and flooding, increased population pressure, and limited non-mangroves based livelihoods. Almost $79 \%$ of the households reported that they had to pay an extra, often illegal, fee to local officials and a group of kidnappers living inside the forest to collect mangroves resources. Salinity intrusion and extreme events were identified as the major risks by 65 and $49 \%$ of the households, respectively. Risks owing to population pressure and limited nonmangroves based livelihoods were recognized by 24 and $17 \%$ of the households, respectively.

A large number of households pointed out that mangrove resources had declined over the last 10 years (Fig. 6). Mangroves deforestation was indicated by almost $56 \%$ households and decline of fisheries production and wildlife were reported by 46 and $31 \%$ households, respectively. About $16 \%$ households considered planting by different government and non-government organizations has increased mangrove cover, while almost $64 \%$ of the households predicted that mangroves services will be further degraded if current trends prevail (Fig. 7). They 
Fig. 4 Ranking of mangroves services as the degree of importance by surveyed households $(\mathrm{n}=100)$ of three villages (i.e., Shinghertoly, Burigoalini and Nil Dumur) in SIZ
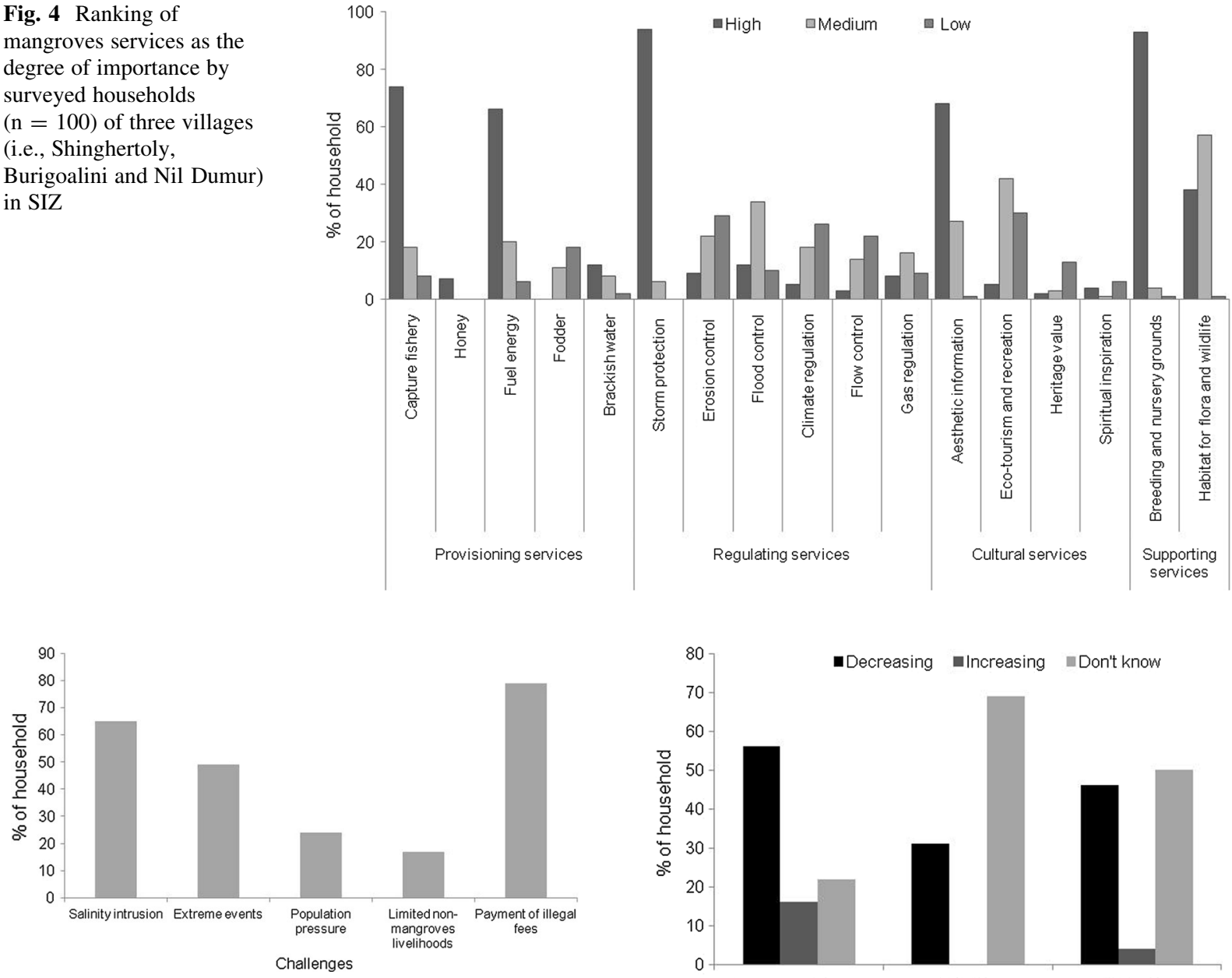

Fig. 5 Challenges of mangroves management and local livelihoods perceived by surveyed households $(n=100)$ of three villages (i.e., Shinghertoly, Burigoalini and Nil Dumur) in SIZ

underlined the importance of proper management of Sundarban mangroves.

Economic values of Sundarban mangroves wetland services

\section{Economic values of provisioning services perceived by the households}

The economic value of provisioning services including capture fishery, fuel energy, fodder and honey were calculated (Table 5). Overall capture fishery generated the highest economic value in all three villages, which was in contrast to the monetary gain from fuel energy, honey and fodder. Across the three

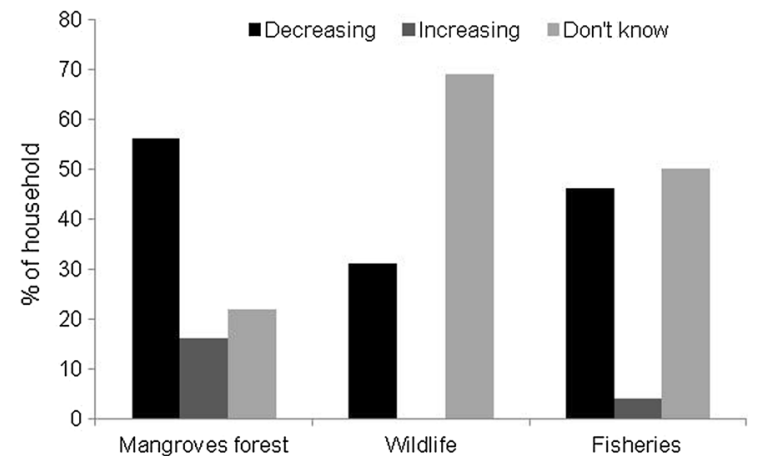

Fig. 6 Present status of mangroves services as perceived by surveyed households $(n=100)$ of three villages (i.e., Shinghertoly, Burigoalini and Nil Dumur) in SIZ

villages, the average annual economic value of capture fishery was estimated at US\$ 1086 per household, or US\$273,049 per village, which implies a total of about US\$ 356 million for all the 1302 villages in SIZ or US\$ 976 per ha. Compared to capture fishery, fuel energy, while benefiting most households, generated relatively a much lower annual economic value estimated at US\$ 64 per household, equating to US\$ 22,315 per village and US\$ 29 million for all village in SIZ or US\$ 80 per ha because of less unit price of firewood. Although only benefiting a small group of households across villages, honey annually generated a relatively high economic value estimated at US\$ 548 per household, which was the second highest among the provision services perceived. 


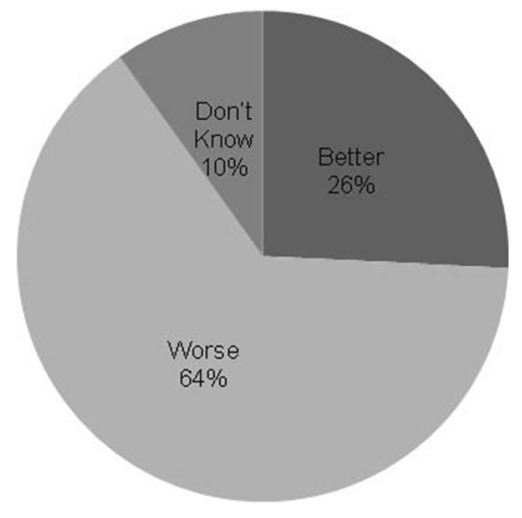

Fig. 7 Future status of mangroves services as perceived by surveyed households $(n=100)$ of three villages (i.e., Shinghertoly, Burigoalini and Nil Dumur) in SIZ

However, on the basis of economic value per village, honey had a relatively low annual economic value, which was estimated at US $\$ 14,788$ per village due to low percentage of households benefiting from the service. While fodder annually generated an economic value of about US\$ 66 per household similar to that of fuel energy, it contributed the least economic value at the village level, due to the low percentage of beneficiary households. The aggregated annual economic values for honey and fodder were estimated at, respectively, US\$ 19.25 million and US\$ 9.51 million for all villages in SIZ. The total economic value of provisioning services was estimated about US\$ 317,500 per village or US\$ 1135 per ha.

\section{Economic values of regulating and supporting services}

Household WTP for two regulating services (storm protection and erosion control) and one supporting service of habitat for fish breeding and nursery service revealed a varied response across households and villages (Table 6). Almost 89\% households were willing to pay for storm protection. This is in contrast to the result that 32 and 52\% households were willing to pay for, respectively, erosion control and habitat for fish breeding and nursery services. Across the three villages, WTP was almost equal for storm protection service. For erosion control, the greatest WTP was in Shinghertoly (US\$ 1145 per year) followed by Burigoalini (US\$ 402 per year) and Nil Dumur (US\$ 191 per year). On the other hand, the maximum WTP for the habitat for fish breeding and nursery service was found in Burigoalini (US\$ 3934 per year) with the least value in Shinghertoly (US\$ 1555 per year).

Household WTPs differed significantly for the three services $(\mathrm{df}=172, \mathrm{~F}=9.276, \mathrm{p}<0.0002$ ). The mean WTP for storm protection was the second highest (US\$ 10 per household per year), but with the highest annual average value per village of US\$ 3519 , which can be extrapolated as US\$ 4.59 million for all the villages in SIZ or US\$ 13 per ha. The annual WTP was the lowest for erosion control (US\$ 5 per household), implying US\$ 579 per village and US\$ 0.75 million for all the villages in SIZ, or US\$ 2 per ha. The mean WTP per household for the habitat for fish breeding and nursery service was the greatest, but their annual value contribution to villages were the second highest at US\$ 2508 per village, US\$ 3.27 million for all the villages in SIZ, or US\$ 9 per ha.

\section{Discussion}

The Sundarban mangrove wetlands of Bangladesh provide important provisioning, regulating, cultural, and supporting services for local livelihoods. While the mangroves are internationally renowned for conservation value, quantifying the ecosystem services of mangroves and their economic value provide a sound rationale for conservation supporting international or national policy commitments and preservation of biodiversity (Badola and Hussain 2005; UNEP/CBD 2010; Uddin et al. 2013a; Haque and Aich 2014; DoE 2016).

Within the Sundarban villages studied, capture fishery contribute an important and direct source of household income (Walters et al. 2008; Hussain and Badola 2010). Almost $79 \%$ of surveyed households are supported by capture fishery. Firewood collection, honey and fodder, while overall providing a modest monetary value, play nevertheless important roles for local subsistence. Mangroves are the primary sources of fuel energy (Walters et al. 2008), but are also a threat to sustainable use of wetlands because of limited alternatives for household cooking and other energy needs. Relatively low frequency activities such as honey production can be a very important supplement to income for some households. This also indicates the value of diverse services provided by mangroves. 
Table 5 Estimated economic values of mangroves provisioning services perceived by surveyed households of three villages (i.e., Shinghertoly, Burigoalini and Nil Dumur) in SIZ

\begin{tabular}{|c|c|c|c|c|c|}
\hline \multirow[t]{2}{*}{ Village attributes } & \multicolumn{4}{|c|}{ Provisioning services } & \multirow[t]{2}{*}{ Total } \\
\hline & Capture fishery & Fuel energy & Honey & Fodder & \\
\hline \multicolumn{6}{|l|}{ Shinghertoly } \\
\hline Number of households in village depending on services & 166 & 323 & 31 & 117 & 323 \\
\hline Percentage of households depending on services, $\%$ & 47 & 91 & 9 & 33 & 91 \\
\hline Average annual value per dependent household, US\$ & 1385 & 58 & 645 & 72 & 858 \\
\hline Annual economic value, US\$ & 229,882 & 18,776 & 19,989 & 8476 & 277,123 \\
\hline Average annual value per ha, US\$ & 822 & 67 & 71 & 30 & 991 \\
\hline \multicolumn{6}{|l|}{ Burigoalini } \\
\hline Number of households in village depending on services & 354 & 440 & 50 & 109 & 452 \\
\hline Percentage of households depending on services, $\%$ & 74 & 92 & 10 & 23 & 94 \\
\hline Average annual value per dependent household, US\$ & 1197 & 56 & 487 & 66 & 1062 \\
\hline Annual economic value, US\$ & 423,614 & 24,586 & 24,376 & 7229 & 479,805 \\
\hline Average annual value per ha, US\$ & 1515 & 88 & 87 & 26 & 1716 \\
\hline \multicolumn{6}{|l|}{ Nil Dumur } \\
\hline Number of households in village depending on services & 234 & 287 & 0 & 105 & 287 \\
\hline Percentage of households depending on services, $\%$ & 76 & 93 & 0 & 34 & 93 \\
\hline Average annual value per dependent household, US\$ & 708 & 82 & 0 & 59 & 681 \\
\hline Annual economic value, US\$ & 165,652 & 23,582 & 0 & 6214 & 195,448 \\
\hline Average annual value per ha, US\$ & 592 & 84 & 0 & 22 & 699 \\
\hline \multicolumn{6}{|l|}{ All three villages } \\
\hline Number of households in villages depending on services & 754 & 1050 & 81 & 331 & 1062 \\
\hline Percentage of households depending on services, $\%$ & 66 & 92 & 7 & 29 & 93 \\
\hline Average annual value per dependent household, US\$ & 1086 & 64 & 548 & 66 & 897 \\
\hline Annual economic value, US\$ & 819,147 & 66,945 & 44,365 & 21,919 & 952,859 \\
\hline Average annual economic value per village, US\$ & 273,049 & 22,315 & 14,788 & 7306 & 317,458 \\
\hline Average annual value per ha, US\$ & 976 & 80 & 53 & 26 & 1135 \\
\hline
\end{tabular}

As a major tropical coastal ecosystem, mangroves support millions of livelihoods globally. Table 7 compares the economic values of mangroves services estimated in this study with those from the literature. For comparison purpose, all estimated values were standardized to the year of 2015 using the consumer price index (CPI) calculator from the Bureau of Labour Statistics of the United States Department of Labour. In comparison with the estimated annual revenue of US\$ 1.26 per ha collected by the Forest Department of Bangladesh as fees for harvesting mangroves products (including timber, firewood, fish, honey) in Sundarban (Uddin et al. 2013a), the standardised annual economic value of mangroves products to local communities was estimated at
US\$ 116 per ha in Thailand (Sathirathai and Barbier 2001), and US\$ 48 per ha in Indonesia (Malik et al. 2015). Value per household of mangrove products estimated in the Bhitarkonika Conservation Area in India was almost US\$ 115 (Hussain and Badola 2010). In this study, the estimated annual value of mangroves products utilized by the local households was US\$ 1135 per ha for Sundarban in Bangladesh.

The elicited economic value for regulating services for Bangladesh Sundarban seems low in comparison with the value estimates in other studies. Specifically, the economic value of regulating services for Bangladesh Sundarban were US $\$ 13$ per ha per year for storm protection, US\$ 2 per ha per year for erosion control, and US\$ 9 per ha per year for habitat of fish breeding 
Table 6 Willingness to pay (WTP) for mangroves regulating and supporting services by surveyed households of three villages (i.e., Shinghertoly, Burigoalini and Nil Dumur) in SIZ

\begin{tabular}{|c|c|c|c|c|}
\hline \multirow[t]{2}{*}{ Village attributes } & \multicolumn{2}{|c|}{ Regulating services } & \multirow{2}{*}{$\begin{array}{l}\text { Supporting } \\
\text { service } \\
\text { Habitat for } \\
\text { fish breeding } \\
\text { and nursery }\end{array}$} & \multirow[t]{2}{*}{ Total } \\
\hline & $\begin{array}{l}\text { Storm } \\
\text { protection }\end{array}$ & $\begin{array}{l}\text { Erosion } \\
\text { control }\end{array}$ & & \\
\hline \multicolumn{5}{|l|}{ Shinghertoly } \\
\hline Number of households in village perceiving the service & 312 & 219 & 124 & 312 \\
\hline Percentage of household willing to pay for the service, $\%$ & 88 & 62 & 35 & 88 \\
\hline Mean annual WTP per household perceiving the service, US\$ & 11 & 5 & 13 & 20 \\
\hline Annual WTP value, US\$ & 3579 & 1145 & 1555 & 6287 \\
\hline Average annual WTP per ha, US\$ & 13 & 4 & 6 & 23 \\
\hline \multicolumn{5}{|l|}{ Burigoalini } \\
\hline Number of households in village perceiving the service & 418 & 94 & 294 & 480 \\
\hline Percentage of household willing to pay for the services, $\%$ & 87 & 20 & 61 & 100 \\
\hline Mean annual WTP per household perceiving the service, US\$ & 10 & 4 & 13 & 17 \\
\hline Annual WTP value, US\$ & 3984 & 402 & 3934 & 8318 \\
\hline Average annual WTP per ha, US\$ & 14 & 1 & 14 & 30 \\
\hline \multicolumn{5}{|l|}{ Nil Dumur } \\
\hline Number of households in village perceiving the service & 286 & 52 & 176 & 299 \\
\hline Percentage of household willing to pay for the service, $\%$ & 93 & 17 & 57 & 97 \\
\hline Mean annual WTP per household perceiving the service, US\$ & 10 & 4 & 12 & 17 \\
\hline Annual WTP value, US\$ & 2994 & 191 & 2035 & 5220 \\
\hline Average annual WTP per ha, US\$ & 11 & 1 & 7 & 19 \\
\hline \multicolumn{5}{|l|}{ All three villages } \\
\hline Number of households in village perceiving the service & 1016 & 365 & 594 & 1085 \\
\hline Percentage of household willing to pay for the service, $\%$ & 89 & 32 & 52 & 95 \\
\hline Mean annual WTP per household perceiving the service, US\$ & 10 & 5 & 13 & 18.28 \\
\hline Average annual WTP per village, US\$ & 3519 & 579 & 2508 & 6608 \\
\hline Average annual WTP per ha, US\$ & 13 & 2 & 9 & 24 \\
\hline
\end{tabular}

and nursery services, respectively. In contrast, Sathirathai and Barbier (2001) estimated the economic value of erosion control at US\$ 4830 per ha per year; Barbier (2007) estimated the economic value of storm protection at about US $\$ 10,057-12,138$ per ha per year; and Malik et al. (2015) estimated the economic value of habitat for breeding and nursery services almost US\$ 2292 per ha per year (Table 7). The difference in the estimated economic value for regulating services may be attributed to the difference possibly mainly in local socio-economic conditions as well as the valuation approach used. It is worth noting that Sathirathai and Barbier (2001) and Barbier (2007) used damage cost avoided and production function while our study employed contingent valuation, which typically generates lower value estimates. The WTP elicited in this study reflects local resident preferences, providing the basis for designing socially acceptable strategies for mangroves management in Sundarban.

Economic valuation of mangroves provisioning services can assist in understanding the role of Sundarban in coastal economic development and for comparing management options. For example, the annual economic value of provisioning services of mangroves utilized by households in the Sundarban was estimated at US\$ 1135 per ha (Table 5), greater than the net economic return at US\$ 713 per ha (or US\$ 773 per ha in 2015) of shrimp (Penaeus monodon) farming (Ferozi et al. 2009). The protective role that the Sundarban mangroves provide in reducing the impact from storm surges and cyclones was well 
Table 7 List of estimated economic values and valuation methods for different mangroves services in different countries

\begin{tabular}{|c|c|c|c|c|}
\hline $\begin{array}{l}\text { Mangroves } \\
\text { location }\end{array}$ & Ecosystem services & $\begin{array}{l}\text { Sources of estimated } \\
\text { value }\end{array}$ & $\begin{array}{l}\text { Estimated } \\
\text { economic } \\
\text { value } \\
\text { (standardized } \\
\text { to } 2015)^{\mathrm{a}} \text {, US\$ } \\
\text { per ha per year }\end{array}$ & $\begin{array}{l}\text { Valuation } \\
\text { methods }\end{array}$ \\
\hline \multirow[t]{6}{*}{ Bangladesh } & Provisioning services & This study (Table 5) & 1135 & Market price \\
\hline & Storm protection & This study (Table 6) & 12.60 & WTP \\
\hline & Erosion control & This study (Table 6) & 2.07 & WTP \\
\hline & Habitat for fish breeding and nursery grounds & This study (Table 6) & 8.97 & WTP \\
\hline & Provisioning services & Uddin et al. (2013a) & 1.26 & $\begin{array}{l}\text { Government } \\
\text { revenue }\end{array}$ \\
\hline & $\begin{array}{l}\text { Nine support function, seven regulatory, five } \\
\text { provisioning and three cultural services }\end{array}$ & $\begin{array}{l}\text { Haque and Aich } \\
\text { (2014) }\end{array}$ & $105-840$ & Delphi method \\
\hline Fiji & On site fisheries & Lal (1990) & $108-432$ & Market price \\
\hline \multirow[t]{3}{*}{ Indonesia } & Provisioning services & Malik et al. (2015) & 48 & Market price \\
\hline & Erosion control & Malik et al. (2015) & $694-3767$ & $\begin{array}{l}\text { Replacement } \\
\text { cost }\end{array}$ \\
\hline & Habitat for nursery grounds & Malik et al. (2015) & 2292 & Benefit transfer \\
\hline Kosrae & Fisheries & $\begin{array}{l}\text { Naylor and Drew } \\
\text { (1998) } \\
\text { Cited in Vo et al. } \\
\text { (2012) }\end{array}$ & 661 & Market price \\
\hline \multirow[t]{3}{*}{ Kenya } & Fisheries & UNEP (2011) & 46 & Market price \\
\hline & Firewood & UNEP (2011) & 17 & Market price \\
\hline & Storm protection & UNEP (2011) & 95 & $\begin{array}{l}\text { Damage cost } \\
\text { avoided }\end{array}$ \\
\hline Mexico & Natural habitat and food supply to fisheries & Cabrera et al. (1998) & 2263 & $\begin{array}{l}\text { Production } \\
\text { function }\end{array}$ \\
\hline \multirow[t]{2}{*}{ Sri Lanka } & Fisheries (lagoon and coastal fishery) & $\begin{array}{l}\text { Gunawardena and } \\
\text { Rowan (2005) }\end{array}$ & 914 & Market price \\
\hline & Erosion control and buffer against storms & $\begin{array}{l}\text { Gunawardena and } \\
\text { Rowan }(2005)\end{array}$ & 360 & $\begin{array}{l}\text { Replacement } \\
\text { cost }\end{array}$ \\
\hline \multirow[t]{6}{*}{ Thailand } & Mangroves products & Barbier (2007) & $543-656$ & Market price \\
\hline & Mangroves products & $\begin{array}{l}\text { Sathirathai and } \\
\text { Barbier (2001) }\end{array}$ & 116 & Market price \\
\hline & Storm protection & Barbier (2007) & $10,057-12,138$ & $\begin{array}{l}\text { Expected } \\
\text { damaged cost }\end{array}$ \\
\hline & Erosion control & $\begin{array}{l}\text { Sathirathai and } \\
\text { Barbier (2001) }\end{array}$ & 4830 & $\begin{array}{l}\text { Replacement } \\
\text { cost }\end{array}$ \\
\hline & Habitat for breeding and nursery services & Barbier (2007) & $794-1107$ & Production \\
\hline & & $\begin{array}{l}\text { Sathirathai and } \\
\text { Barbier (2001) }\end{array}$ & $28-91$ & function \\
\hline
\end{tabular}

$\overline{{ }^{a} \text { Based on consumer price index (CPI) inflation calculator, Bureau of Labor Statistics, The United States Department of Labor }}$ (https://www.bls.gov/data/inflation-calculator.htm)

recognised by the communities. Indeed, the physical and economic protection offered by mangrove forests is well established (Lal 2002; Badola and Hussain
2005; Barbier 2007). According to Massel et al. (1999), mangroves can absorb $75 \%$ of wave energy when passing through 200 meters of mangroves. 
Mazda et al. (1997) estimates that a $1.5 \mathrm{~km}$ belt of mangroves can fully attenuate energy from the waves of $1 \mathrm{~m}$. Sundarban mangroves support extensive fishery by providing habitat and protection for fish breeding and nursery for fish and shellfish (Beck et al. 2001; Lee 2008; Hussain et al. 2014). In Southeast Asia $30 \%$ of fish and $100 \%$ of prawn catches are mangrove-related species (Ronnback 1999).

The surveyed households of the Sundarban perceived that mangroves services were of moderate to low importance for stabilizing coastal areas by reducing erosion, mitigating flood impact, regulating water flow and local climate system. This suggests that local residents may not be fully aware of the wide ecological benefits of mangroves, and their direct or indirect link to human wellbeing and livelihoods. This, further, suggests that building awareness and participation of local communities can also support ICZM of the area. Various awareness-raising programmes should thereby be an important management strategy to improve local understanding of not only the socioecological linkages of mangroves and their roles in supporting human well-beings but also their conservation value. It should ensure that community stakeholders are involved in mangroves management, which can improve the sense of ownership of local resources and increase the awareness of the benefits of mangrove management and conservation.

Households WTPs for storm protection and habitat for fish breeding and nursery services imply that Sundarban mangroves have important indirect use value for local communities. The elicited WTPs can provide information about local people's preferences, perceived relative importance of different services, and the rationale and awareness that conservation of mangroves can produce valuable mangroves services that are locally desirable to the wellbeing of coastal communities.

Various pressures contribute to the degradation of Sundarban mangroves. The major causes include overexploitation to meet the rising demand of growing population, illegal activities and salinity intrusion due to anthropogenic and natural disturbances posing tremendous pressure on the sustainable provision of mangroves services and the wellbeing of coastal communities (Islam and Gnauck 2008; Rahman et al. 2010; Getzner and Islam 2013; Uddin et al. 2013b; Hussain 2014). The extent to which mangroves offer services depend on, among others, habitat extent and condition of the ecosystem (Dahdouh-Guebas et al. 2005; Alongi 2008). Unsustainable exploitation of mangroves resources may produce immediate benefits but in the medium to longer term undermine the continuous delivery of the wide services of ecosystems (Carpenter et al. 2009; Mukherjee et al. 2014).

Degradation of Sundarban mangroves highlights the importance of regulatory enforcement, conservation of the existing stock, and restoration of the degraded mangroves to safeguard the ecosystem services for adaptation to the impact of climate change and for the wellbeing of coastal communities of Bangladesh. There is considerable scope for better implementation of existing regulations and attention to integrated management of the Sundarban mangroves. We recommend development of alternative livelihoods schemes, particularly during the period of restriction on harvest of mangroves resources. Development alternatives also reduce local dependency on mangroves and promote the recovery of ecosystems after exploitation. Furthermore, improving polices and strategies that consider the value of mangroves to local communities will aid mangrove conservation decision-making. Existing policies perpetuate traditional economic development views of generating revenue from the production of timber, other minor forest and aquatic products, while sustainable fishery management and ecological services maintenance have largely been overlooked in current policies (Hussain 2014). A comprehensive assessment of mangroves socio-ecological linkages is needed to integrate development planning with conservation for the Sundarban and SIZ.

This study has provided preliminary information on the value of ecosystem services of Sundarban mangroves useful for informed decision-making related to Sundarban mangroves. These values should be taken into account in mangroves management and development planning in a context such as cost-benefit analysis. The results of the estimated economic values of mangroves services can be used to evaluate and compare ecosystem consequences of different management options and to identify the priorities contributing to mangroves conservation, restoration and local wellbeing in the coastal areas of Bangladesh. The above information can also serve as the benchmark for the mangroves conservation benefits to local communities and for further research on the economic values of mangroves wetlands in Bangladesh. 


\section{Conclusion}

Sundarban mangroves are central to the livelihood and wellbeing of the coastal communities in Bangladesh who depend on and benefit from the wide services provided by the ecosystem. Despite their considerable socio-economic value, Sundarban mangroves have been degrading over the past decade, threatening and endangering the wellbeing of coastal communities and their long-run sustainability. While unsustainable use and poor management contributed directly to the degradation of Sundarban mangroves, the current lack of understanding of the services in quantitative terms and their monetary value is commonly considered a fundamental reason for the overexploitation of mangroves without conservation in development decisionmaking. Quantifying the mangrove services and their economic value and incorporating them in management decision-making are recognized and increasingly advocated as an important strategy for promoting the conservation and wise use of mangroves.

This study adopted the ecosystem services framework to evaluate the importance and conservation value of Sundarban mangroves to coastal communities in Bangladesh. In this study, we conducted household survey in three coastal villages in the Sundarban area to identify mangrove services as perceived by local communities and to estimate the economic value of these services. Our survey results indicated 18 mangroves services, of which capture fishery, fuel energy, storm protection, habitat for fish breeding and nursery grounds, and aesthetic amenity were ranked by respondents the most important. For provisioning services, their annual economic value was estimated at US\$ 976 per ha for capture fishery, US\$ 80 per ha for fuel energy, US\$ 53 per ha for honey, and US\$ 26 per ha for fodder. The average annual willingness to pay for storm protection, erosion control and habitat for fish breeding and nursery services were, respectively, US\$ 13 per ha, US\$ 2 per ha, and US\$ 9 per ha. This study provides important insights into the services and values of mangroves for local welfare, and can inform development decision-making and mangroves management promoting wise use and conservation.

Acknowledgements The Joint Japan/World Bank Graduate Scholarship Program (JJ/WBGSP) and the UNESCO-IHE Institute for Water Education provided financial support for the research for partial fulfilment of Master of Science in Limnology and Wetland Management in the UNESCO-IHE Institute for Water Education, Delft, the Netherlands. The authors are grateful to the anonymous reviewers for the insightful comments in improving the manuscript. We acknowledge the support of Caritas Bangladesh and IUCN Bangladesh during data collection. We also want to thank the surveyed households for providing valuable information for the study.

Open Access This article is distributed under the terms of the Creative Commons Attribution 4.0 International License (http:// creativecommons.org/licenses/by/4.0/), which permits unrestricted use, distribution, and reproduction in any medium, provided you give appropriate credit to the original author(s) and the source, provide a link to the Creative Commons license, and indicate if changes were made.

\section{References}

Alongi DM (2002) Present state and future of the world's mangrove forests. Environ Conserv 29:331-349

Alongi DM (2008) Mangrove forests: resilience, protection from tsunamis, and responses to global climate change. Estuar Coast Shelf Sci 76:1-13

Badola R, Hussain SA (2005) Valuing ecosystem functions: an empirical study on the storm protection function of Bhitarkanika mangrove ecosystem, India. Environ Conserv 32(1):85-92

Barbier EB (2007) Valuing ecosystem services as productive inputs. Econ Policy 22:177-229

Bateman IJ, Harwood AR, Mace GM, Watson RT, Abson DJ et al (2013) Bringing ecosystem services into economic decision-making: land use in the United Kingdom. Science 341:45-50

Beck MW, Heck KLJ, Able KW, Childers DL, Eggleston DB, Gillanders BM, Halpern B, Hays CG, Hoshino K, Minello TJ (2001) The identification, conservation, and management of estuarine and marine nurseries for fish and invertebrates. Bioscience 51(8):633-641

Biswas SR, Choudhury JK, Nishat A, Rahman MM (2007) Do invasive plants threaten the Sundarbans mangrove forest of Bangladesh? For Ecol Manag 245(1):1-9

Brander LM, Wagtendonk AJ, Hussain SS, McVittie A, Verburg PH, de Groot RS, van der Ploeg S (2012) Ecosystem service values for mangroves in Southeast Asia: a metaanalysis and value transfer application. Ecosyst Serv 1:62-69

Cabrera MA, Seijo JC, Euan J, Perez E (1998) Economic values of ecological services from a mangrove ecosystem. Intercoast Netw 32:1-2

Carpenter SR, Mooney HA, Agard J, Capistrano D, Defries RS, Díaz S et al (2009) Science for managingecosystem services: beyond the millennium ecosystem assessment. Proc Natl Acad Sci 106(5):1305-1312

Chee YE (2004) An ecological perspective on the valuation of ecosystem services. Biol Conserv 120:549-565 
Costanza R, Farber S (2002) Introduction to the special issue on the dynamics and value of ecosystem services: integrating economic and ecological perspectives. Ecol Econ 41(3):367-373

Curtis IA (2004) Valuing ecosystem goods and services: a new approach using a surrogate market and the combination of a multiple criteria analysis and a Delphi panel to assign weights to the attributes. Ecol Econ 50:163-194

Dahdouh-Guebas F, Jayatissa LP, Di Nitto D, Bosire JO, Seen DL, Koedam N (2005) How effective were mangroves as a defence against the recent tsunami? Curr Biol 15(12):443-447

Daily GC (1997) Valuing and safeguarding earth's life support systems. In: Daily GC (ed) Nature services-societal dependence on natural ecosystems. Island Press, Washington DC, pp 365-374

Daily GC, Alexander S, Ehrlich PR, Goulder L, Lubchenco J, Matson PA, Mooney HA, Postel S, Schneider SH, Tilman D, Woodwell GM (1997) Ecosystem service: benefits supplied to human societies by natural ecosystems. Ecology $2: 1-15$

DoE (Department of Environment) (2016) National biodiversity strategy and action plan of Bangladesh 2016-2021. Ministry of Environment and Forests, Government of Bangladesh, Dhaka

FAO (Food and Agriculture Organization of the United Nations) (2010) Global forest resources assessment 2010-Main Report. FAO Forestry Paper 163, Rome

FD (Forest Department) (2010) Integrated resources management plan for Sundarbans (2010-2020). Ministry of Environment and Forest, Government of Bangladesh, Dhaka

Ferozi ANMW, Rashid MHA, Hossain M (2009) Profitability analysis of Bagda farming in some selected areas of Satkhira district. Prog Agric 20(1\&2):221-229

Getzner M, Islam MS (2013) Natural resources, livelihoods, and reserve management: a case study from Sundarbans mangrove forests, Bangladesh. WIT Trans Ecol Environ $8(1): 75-87$

Giri C, Pengra B, Zhu Z, Singh A, Tieszen LL (2007) Monitoring mangrove forest dynamics of the Sundarbans in Bangladesh and India using multi-temporal satellite data from 1973 to 2000. Estuar Coast Shelf 73(1):91-100

Gunawardena M, Rowan JS (2005) Economic valuation of a mangrove ecosystem threatened by Shrimp aquaculture in Sri Lanka. Environ Manag 36(4):535-550. https://doi.org/ 10.1007/s00267-003-0286-9

Halim S, Mallick D, Reza O, Hasan SR, Kabir SA (2001) Feasibility study for the shrimp component of the fourth fisheries project-women and children study. Bangladesh Centre for Advanced Studies, Dhaka

Haque AKE, Aich D (2014) Economic valuation of ecosystem services. In: Hussain MZ (ed) Bangladesh Sundarban delta vision 2050: A first step in its formulation-document 2: a compilation of background information. IUCN-International Union for Conservation of Nature, Bangladesh Country office, Dhaka, pp 55-63

Hoq ME (2007) An analysis of fisheries exploitation and management practices in Sundarbans mangrove ecosystem, Bangladesh. Ocean Coast Manag 50(5):411-427
Hussain MZ (2014) Issues and challenges. In: Hussain MZ (ed) Bangladesh Sundarban delta vision 2050: A first step in its formulation-document 2: a compilation of background information. IUCN-International Union for Conservation of Nature, Bangladesh Country Office, Dhaka, pp 85-101

Hussain SA, Badola R (2010) Valuing mangrove benefits: contribution of mangrove forests to local livelihoods in Bhitarkanika conservation area, East Coast of India. Wetl Ecol Manag 18(3):321-331

Hussain MZ, Khan MH, Hossain A, Rouf MA (2014) Resources and services. In: Hussain MZ (ed) Bangladesh Sundarban delta vision 2050: A first step in its formulation-document 2: a compilation of background information. IUCNInternational Union for Conservation of Nature, Bangladesh Country Office, Dhaka, pp 37-53

Iftekhar M (2008) An overview of mangrove management strategies in three South Asian countries: Bangladesh, India and Sri Lanka. Int For Rev 10(1):38-51

Iftekhar M, Islam M (2004) Degeneration of Bangladesh's Sundarbans mangroves: a management issue. Int For Rev 6(2):123-135

Iftekhar M, Takama T (2008) Perceptions of biodiversity, environmental services, and conservation of planted mangroves: a case study on Nijhum Dwip Island, Bangladesh. Wetl Ecol Manag 16(2):119-137

IPCC (Intergovernmental Panal on Climate Change) (2014) Climate Change 2014: Impacts, adaptation and vulnerability. Part A: global and sectoral aspects. Contributionof working group II to the fifth assessment report of the Intergovernmental panal on climate change, Cambridge University Press, New York

Islam SN, Gnauck A (2008) Mangrove wetland ecosystems in Ganges-Brahmaputra delta in Bangladesh. Front Earth Sci China 2(4):439-448

Islam MS, Wahab MA (2005) A review on the present status and management of mangrove wetland habitat resources in Bangladesh with emphasis on mangrove fisheries and aquaculture. In: Segers H, Martens K (ed) Aquatic Biodiversity II: The diversity of aquatic ecosystems. Hydrobiologia 542(1): 165-190

IUCN (International Union for Conservation of Nature) (2014) Bangladesh Sundarban delta vision 2050: a first step in its formulation-document 1: the vision. IUCN, Bangladesh Country office, Dhaka

Khan SE (2014) Policy perspectives. In: Hussain MZ (ed) Bangladesh Sundarban delta vision 2050: a first step in its formulation-document 2: a compilation of background information, Bangladesh Country Office. IUCN-International Union for Conservation of Nature, Dhaka, pp 71-83

Lal PN (1990) Conservation or conversion of mangroves in Fiji: An ecological economic analysis. Occasional Paper No. 11, East-West Environment and PolicyInstitute, Honolulu

Lal PN (2002) Integrated and adaptive mangrove management framework-anaction oriented option for the newmillennium. In: LacerdaLD (ed) MangroveEcosystems: Function and management. Springer, Berlin, pp 235-256

Lee SY (2008) Mangrove macrobenthos: assemblages, services, and linkages. J Sea Res 59(1):16-29

Malik A, Fensholt R, Mertz O (2015) Economic valuation of mangroves for comparison with commercial aquaculture in 
South Sulawesi, Indonesia. Forests 6:3028-3044. https:// doi.org/10.3390/f6093028

Massel S, Furukawa K, Brinkman R (1999) Surface wave propagation in mangrove forests. Fluid Dyn Res 24(4):219-249

Mazda Y, Magi M, Kogo M, Hong P (1997) Mangroves as a coastal protection from waves in the Tong King delta, Vietnam. Mangroves Salt Marshes 1(2):127-135. https:// doi.org/10.1023/A:1009928003700

MEA (Millennium Ecosystem Assessment) (2005) Ecosystems and human well-being: wetlands and water synthesis. World Res Inst, Washington DC

MoWR (Ministry of Water Resources) (2005) Coastal zone policy 2005. Government of Bangladesh, Dhaka

Mukherjee N, Sutherland WJ, Dicks L, Huge J, Koedam N, Dahdouh-Guebas F (2014) Ecosystem service valuations of mangrove ecosystems to inform decision making and future valuation exercises. PLoS ONE 9(9):e107706. https://doi.org/10.1371/journal.pone.0107706

Naylor RL, Drew M (1998) Valuing mangrove resources in Kosrae, Micronesia. Environ Dev Econ 3:471-490

NRC (National Research Council) (2005) Valuing ecosystem services: toward better environmental decision making. National Academic Press, Washington DC

Pokrant B (2014) Brackish water shrimp farming and the growth of aquatic monocultures in coastal Bangladesh. In: Christensen J, Tull M (ed), Historical perspectives of fisheries exploitation in the Indo-Pacific, MARE Publication Series 12, Springer Science + Business Media Dordrecht, pp 107-132. https://doi.org/10.1007/978-94-017-8727-7_6

Rahman MM, Rahman M, Islam K (2010) The causes of deterioration of Sundarban mangrove forest ecosystemof Bangladesh: conservation and sustainable management issues. AACL Bioflux 3:77-90

Ronnback P (1999) The ecological basis for economic value of seafood production supported by mangrove ecosystems. Ecol Econ 29(2):235-252

Sathirathai S, Barbier EB (2001) Valuing mangrove conservation in southern Thailand. Contemp Econ Policy 19(2):109-122

Shah MAR, Khan SE (2014) Socio economic perspectives. In: Hussain MZ (ed) Bangladesh Sundarban delta vison 2050: a first step in its formulation-document 2: a compilation of background information. IUCN-International Union for Conservation of Nature, Bangladesh Country Office, Dhaka, pp 29-35

TEEB (The Economics of Ecosystems and Biodiversity) (2009) The economics of ecosystems and biodiversity for national and international policy makers-summary: responding to the value of nature 2009. Welzel + Hardt, Wesseling

TEEB (The Economics of Ecosystems and Biodiversity) (2010) Mainstreaming the economics of nature: a synthesis of the approach, conclusions and recommendations of TEEB. Progress Press, Malta

Turner RK, Georgiou S, Fisher B (2008) Valuing ecosystem services: the case of multi-functional wetlands. Earthscan London, UK

Uddin MS, van Steveninck ED, Stuip M, Shah MA (2013a) Economic valuation of provisioning and cultural services of a protected mangrove ecosystem: a case study on Sundarbans Reserve Forest, Bangladesh. Ecosyst Serv 5:88-93

Uddin MS, Shah MAR, Khanom S, Nesha MK (2013b) Climate change impacts on the Sundarbans mangrove ecosystem services and dependent livelihoods in Bangladesh. Asian J Conserv Biol 2(2):152-156

UNEP (United Nation Environment Programme) (2011) Economic analysis of mangrove forests: a case study in Gazi Bay, Kenya. United Nations Environment Programme, Kenya

UNEP/CBD (United Nation Environment Programme/Convention of Biological Diversity) (2010) The strategic plan for biodiversity 2011-2020 and the Aichi biodiversity targets. Conference of the parties to the convention of biological diversity, Tenth meeting (UNEP/CBD/COP/ $\mathrm{DEC} / \mathrm{X} / 2)$, Nagoya

Vo QT, Kuenzer C, Vo QM, Moder F, Oppelt N (2012) Review of valuation methods for mangrove ecosystem services. Ecol Ind 23:431-446

Walters BB, Ronnback P, Kovacs JM, Crona B, Hussain SA, Badola R, Primavera JH, Barbier E, Dahdouh-Guebas F (2008) Ethnobiology, socio-economics and management of mangrove forests: a review. Aquat Bot 89(2):220-236 